ISSN 1330-3651 (Print), ISSN 1848-6339 (Online) https://doi.org/10.17559/TV-20150924194102

\title{
DETECTION OF SHORT-CIRCUITS OF DC MOTOR USING THERMOGRAPHIC IMAGES, BINARIZATION AND K-NN CLASSIFIER
}

\author{
Adam Glowacz, Andrzej Glowacz, Zygfryd Glowacz
}

Original scientific paper

Many fault diagnostic methods have been developed in recent years. One of them is thermography. It is a safe and non-invasive method of diagnostic. Fault diagnostic method of incipient states of Direct Current motor was described in the article. Thermographic images of the commutator of Direct Current motor were used in an analysis. Two kinds of thermographic images were analysed: thermographic image of commutator of healthy DC motor, thermographic image of commutator of DC motor with shorted rotor coils. The analysis was carried out for image processing methods such as: extraction of magenta colour, binarization, sum of vertical pixels and sum of all pixels in the image. Classification was conducted for K-Nearest Neighbour classifier. The results of analysis show that the proposed method is efficient. It can be also used for diagnostic purposes in industrial plants.

Keywords: diagnostics; DC motor; K-NN classifier; maintenance; thermographic images

\section{Otkrivanje kratkih spojeva istosmjernog motora primjenom termografskih slika, binarizacije i K-NN klasifikatora}

Izvorni znanstveni članak Zadnjih je godina otkriveno mnogo metoda za otkrivanje greške. Jedna od njih je termografija, sigurna i neinvazivna metoda. U radu se opisuje otkrivanje početnog stanja greške u istosmjernom motoru. Analizirane su termografske slike ispravljača istosmjernog motora. Analizirane su dvije vrste termografskih slika: termografska slika ispravljača ispravnog istosmjernog motora i termografska slika ispravljača istosmjernog motora s pregorjelim zavojnicama rotora. Analiza je provedena za metode obrade slike kao što su: ekstrakcija grimizno ljubičaste boje, binarizacija, zbir vertikalnih piksela i zbir svih piksela na slici. Klasifikacija se provela za klasifikator K-Najbliži Susjed (K-Nearest Neighbour classifier). Rezultati analize pokazuju da je predložena metoda učinkovita. Može se također koristiti u dijagnostičke svrhe u industrijskim pogonima.

Ključne riječi: dijagnostika; istismjerni motor; K-NN klasifikator; održavanje; termografske slike

\section{Introduction}

Thermal radiation is produced by any object whose temperature is warmer than absolute zero $\left(-273.15^{\circ} \mathrm{C}\right)$. Thermography is the process of acquisition of thermographic images. In order to identify and analyze thermal anomalies, it is beneficial to use thermography. Thermography allows locating temperature differences of parts of electrical motors. The faulty states of operations of electrical motors are associated with the thermal anomalies. For example shorted rotor coils of electrical motor cause temperature increase. Next this heat is liberated at a rate greater than in the surrounding area. Faulty states are usually caused by friction, misalignment, worn components, deteriorated connections, short circuits, overloads and load imbalances. Thermography can help detect costly failure before it appears $[1 \div 7]$. It is very common to find a loose connection that can be repaired inexpensively. If the electrical motor is allowed to fail, the cost could be high for replacement. The failure of the motor could also result in a major production outage [1]. Fault diagnostic methods and online monitoring were developed for various purposes in the literature $[8 \div 20]$. Fault diagnostic methods of rotating machines based on electrical, acoustic and thermal signals were also described $[21 \div 32]$. Of course the best diagnostic systems should use all of them. In this paper, the authors proposed a new method of fault diagnostics of thermographic images of DC motor (Fig. 1).

The article is divided in 4 different sections. Section 1 presents applications of thermography and literature survey of fault diagnostic methods of electrical machines. Section 2 describes the proposed method of fault diagnostics. Section 3 presents analysis of thermographic images of DC motor. Section 4 describes conclusions and proposition for future researches.

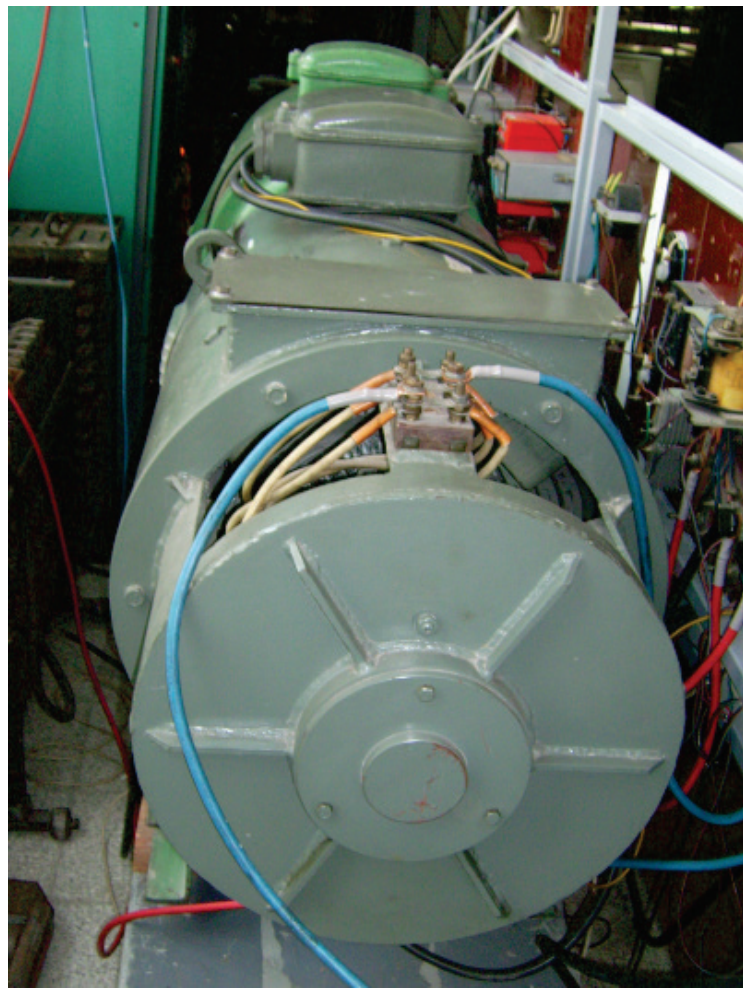

Figure 1 Analyzed Direct Current motor

\section{Fault diagnostic method of thermographic images of} DC motor

Fault diagnostic method of thermographic images of DC motor is presented in Fig. 2. The method started with 
recording a sequence of thermographic images by using thermographic camera. Next recorded sequence was split into thermographic images. After that extraction of magenta color and binarization were performed. Next feature vectors were formed. These feature vectors (processed samples) belonged to training set and test set. Training set was used to create patterns (Patterns creation). Test set was used by K-Nearest Neighbor classifier (Identification). In the identification step feature vectors from test set were compared with feature vectors from training set. The result of the recognition was the name of the state of DC motor, for example "healthy DC motor" or "DC motor with shorted rotor coils".

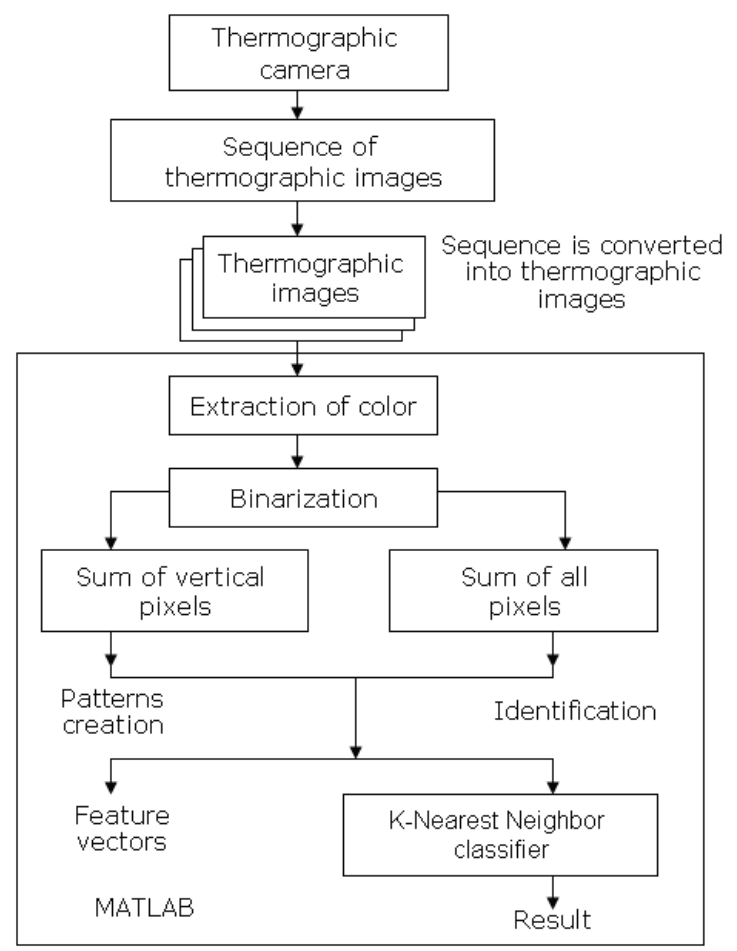

Figure 2 Fault diagnostic method of thermographic images of DC motor using extraction of color, binarization, sum of vertical pixels, sum of all pixels, K-Nearest Neighbor classifier

\subsection{Recording of a sequence of thermographic images}

Thermographic camera was used for recording of a sequence of thermographic images. It was installed $0.3 \mathrm{~m}$ in front of commutator of DC motor (Fig. 3).

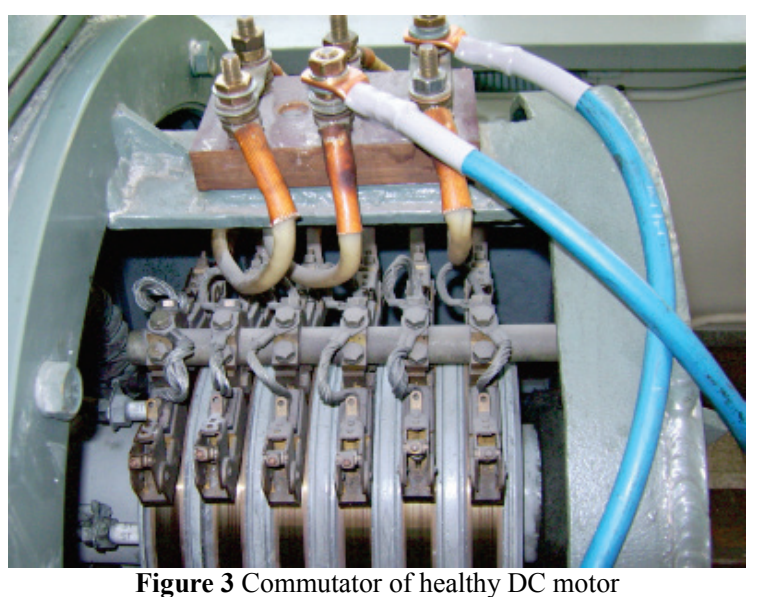

Obtained thermographic images had a resolution of $720 \times 576$ pixels (Fig. 4a, 5a). Sequence of images was saved with a resolution of 24 bits (16 777216 of colors). This sequence of thermographic images was saved on a $\mathrm{PC}$ in AVI (Audio Video Interleave) format. The frame rate was equal to $9 \mathrm{~Hz}$.

\subsection{Acquisition of thermographic images}

1 second of sequence of thermographic images had 9 images $(9 \mathrm{~Hz})$. This sequence had 5 seconds, so 45 thermographic images were obtained for each state of DC motor. To obtain thermographic image mplayer library was used. Mplayer could split sequence of thermographic images into a certain number of images, depending on the parameters of the sequence.

\subsection{Extraction of magenta colour}

MATLAB software was used to extract magenta color from the image. MATLAB used CMY color model, so the image consisted of 3 colors: cyan, magenta and yellow (CMY). On the obtained images higher temperatures were marked by red. Red consisted of magenta and yellow. Lower temperatures were marked by blue. Average temperatures were marked by yellow. It was noticed that magenta had the biggest influence on higher temperatures, so only this color was analyzed. There are more solutions of this problem for example using RGB color space.

Thermographic images and magenta color of images of commutator of DC motor are presented in Figs. $4 \div 5$. Figs. $4 \mathrm{~b}$ and $5 \mathrm{~b}$ are monochrome images. a)

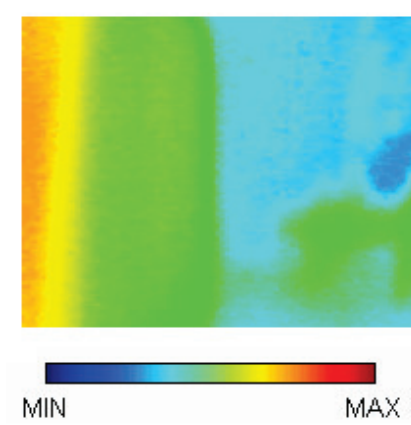

Figure 4 a) Thermographic image of commutator of healthy DC motor, b) Magenta color of thermographic image of commutator of healthy DC motor

a)

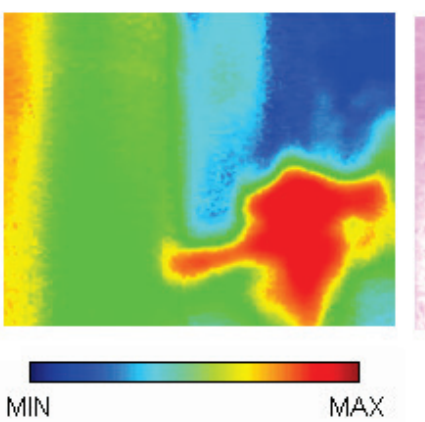

b)

b)

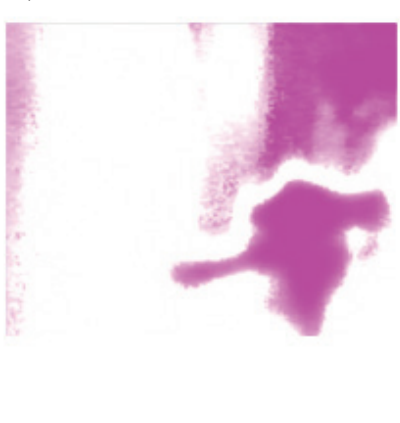

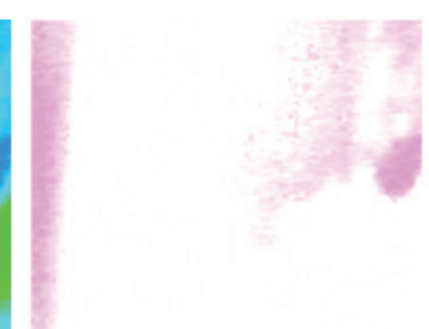

Figure 5 a) Thermographic image of commutator of shorted DC motor, b) Magenta color of thermographic image of commutator of shorted DC motor 


\subsection{Binarization}

Image binarization converted grayscale image into binary image using a thresholding operation. The method replaced each pixel in an image with a black pixel or white pixel depending on threshold value [28]. In this paper, the authors used threshold below, $I<T$, where $I$ image intensity, $T$ - threshold. If $I$ was less than $T$ then $I$ was replaced by white pixel (value 1). To choose the correct binarization threshold $T$, analysis was performed using sum of vertical pixels, sum of all pixels and K-NN classifier $(K=1)$. EoRoCTI was defined by formula (2) in Section 3. In analysis, the authors set $T=0.1$ in the range $<0,1>$, however another binarization threshold $T$ (Tab. 1) will also give good results.

Table 1 Results of recognition of thermographic images of DC motor using sum of vertical pixels, sum of all pixels and K-NN classifier

\begin{tabular}{|c|c|c|c|}
\hline$K=1$ & $T=0.001$ & $T=0.01$ & $T=0.1$ \\
\hline $\operatorname{EoRoCTI}(\%)$ & 100 & 100 & 100 \\
\hline$K=1$ & $T=0.3$ & $T=0.5$ & $T=0.7$ \\
\hline $\operatorname{EoRoCTI}(\%)$ & 100 & 100 & 100 \\
\hline$K=1$ & $T=0.9$ & $T=0.99$ & $T=0.999$ \\
\hline $\operatorname{EoRoCTI}(\%)$ & 100 & 100 & 100 \\
\hline
\end{tabular}

Magenta color of thermographic images of commutator of DC motor after binarization for $T=0.1$ is presented in Fig. 6.

a)

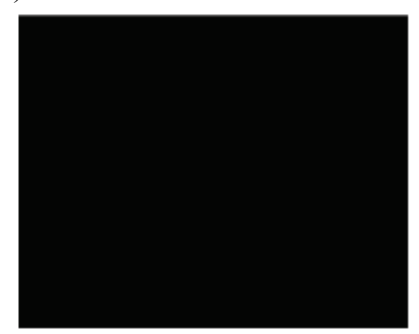

b)

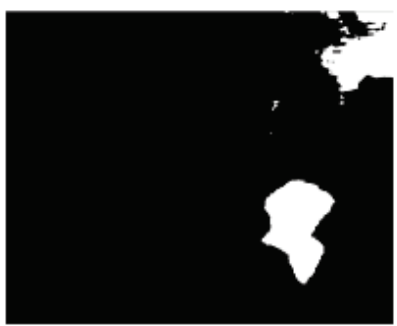

Figure 6 a) Magenta color of thermographic image of commutator of healthy DC motor after binarization for $T=0.1$, b) Magenta color of thermographic image of commutator of shorted DC motor after binarization for $T=0.1$

\subsection{Feature vectors}

Feature extraction of images was described in the literature $[33 \div 37]$. In this paper, the authors proposed the method based on sum of vertical pixels. Values of vertical pixels were summed to form feature vectors. Sum of vertical pixels for image $720 \times 576$ pixels gave 720 features $\boldsymbol{s} \boldsymbol{v}=\left[s v_{1}, s v_{2}, \ldots, s v_{720}\right]$. Next all pixels in the image were summed - variable $s a_{721}$. This feature had index 721, so feature vector was the following: $s=\left[s v_{1}\right.$, $\left.s v_{2}, \ldots, s v_{720}, s a_{721}\right]$. Feature vector ( $s-$ sum of vertical pixels and sum of all pixels) of binary image of healthy DC motor is presented in Fig. 7. Feature vector of binary image of DC motor with shorted rotor coils is presented in Fig. 8.

Obtained feature vectors were used by K-Nearest Neighbor classifier.

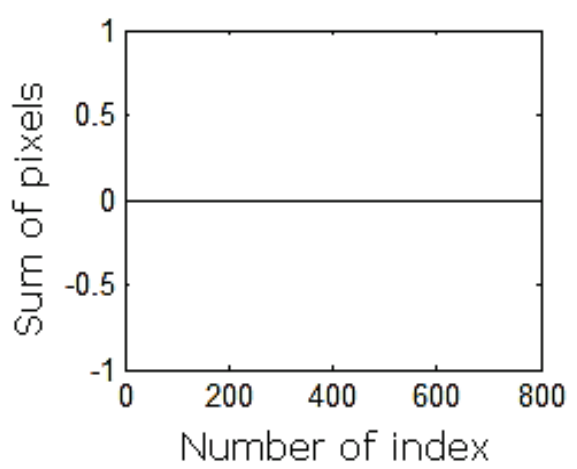

Figure 7 Feature vector of binary image of healthy DC motor

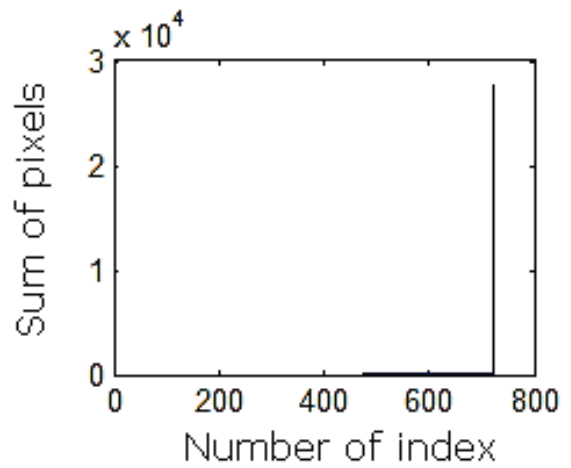

Figure 8 Feature vector of binary image of DC motor with shorted rotor coils

\subsection{K-Nearest Neighbor classifier}

Classification of data was discussed in the literature. Many methods of classification were developed such as: K-Nearest Neighbor, Nearest Mean, Backpropagation Neural Network, classifier based on words, Fuzzy Logic, Genetic algorithms, Support Vector Machine, decision tree $[38 \div 56]$. The K-NN classifier was very good to classify high dimensional feature vector - 721 dimensions. The mentioned classifier could be used with various distance functions such as: Manhattan, Euclidean, Minkowski, Jacquard distance. The results of these functions were very similar, so in conducted analysis Manhattan distance was used. Manhattan distance $d_{m}$ was defined as the distance between two feature vectors. For feature vectors $\boldsymbol{s} \boldsymbol{v} \boldsymbol{a}=\left[s v a_{1}, s v a_{2}, \ldots, s v a_{n}\right]$ and $\boldsymbol{s} \boldsymbol{v} \boldsymbol{b}=\left[s v b_{1}\right.$, $\left.s v b_{2}, \ldots, s v b_{n}\right]$ it was expressed by formula (1):

$d_{m}(\boldsymbol{s v a}, \boldsymbol{s v} \boldsymbol{b})=\sum_{i=1}^{n}\left|\left(s v a_{i}-s v b_{i}\right)\right|$

When all distances for test and training samples were calculated. The majority decision rule was used to identify the state of DC motor.

\section{Analysis of recognition of thermographic images of commutator of DC motor}

Analysis of recognition of thermographic images of commutator of DC motor was conducted for 2 states of motor: healthy DC motor, shorted DC motor (Fig. 9a, 9b). Analyzed DC motor was powered by a generator. Analyzed DC motor had following operation parameters: 
$P_{\text {Nom }}=13 \mathrm{~kW}, U_{\text {Nom }}=75 \mathrm{~V}, U_{\mathrm{AG}}=170 \mathrm{~V}, I_{\text {shorted }}=420$ $\mathrm{A}, R_{\text {shorted }}=4 \mathrm{~m} \Omega, V_{\mathrm{s}}=700 \mathrm{rpm}$.

Where $P_{\text {Nom }}$ - motor power, $U_{\text {Nom }}$ - nominal motor voltage, $U_{\mathrm{AG}}$ - voltage of the generator, $I_{\text {shorted }}$ - shortcircuit current, $R_{\text {shorted }}$ - short-circuit resistance, $V_{\mathrm{s}}$ - rotor speed.

Group of three loops of rotor coils were shorted. It is presented in Fig. 9b.

a)

\section{Healthy rotor coils}

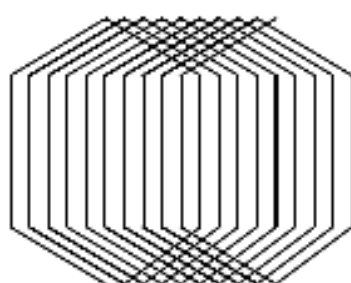

b)

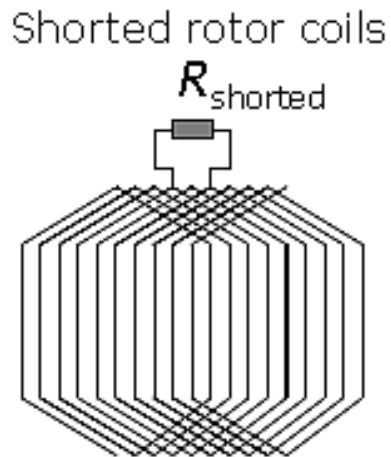

Figure 9 a) Scheme of rotor windings of healthy DC motor, b) Scheme of rotor windings of DC motor with 3 shorted rotor coils

Analysis was conducted for 80 test samples and 10 training samples (thermographic images). Efficiency of recognition of thermographic image was expressed by:

EoRoCTI $=\frac{\text { NoTCTI }}{\text { NoATCTI }} 100 \%$

Where: EoRoCTI - efficiency of recognition of thermographic image, NoTCTI - number of test thermographic images (test samples) identified properly, NoATCTI - number of all test thermographic images.

The results of recognition of thermographic images of commutator of DC motor are presented in Tabs. 2 and 3. Value of EoRoCTI was in range of $92.5 \div 100 \%$ for feature vector consisted of sum of vertical pixels and sum of all pixels (Tab. 2). Value of EoRoCTI was in range of $90 \div 100 \%$ for feature vector only consisted of sum of vertical pixels (Tab. 3 ).

Table 2 Results of recognition of thermographic images of commutator of DC motor using sum of vertical pixels, sum of all pixels and K-NN classifier depending on parameter $K$

\begin{tabular}{|c|c|c|}
\hline \multirow{2}{*}{$K=1$} & State of DC motor & EoRoCTI (\%) \\
\hline \multirow{2}{*}{$K=3$} & Healthy DC motor & 100 \\
\cline { 2 - 3 } & Shorted DC motor & 100 \\
\cline { 2 - 3 } & Healthy DC motor & 100 \\
\hline \multirow{2}{*}{$K=5$} & Shorted DC motor & 100 \\
\cline { 2 - 3 } & Healthy DC motor & 100 \\
\hline
\end{tabular}

Table 3 Results of recognition of thermographic images of commutator of DC motor using sum of vertical pixels and K-NN classifier depending on parameter $K$

\begin{tabular}{|c|c|c|}
\hline \multirow{2}{*}{$K=1$} & State of DC motor & EoRoCTI (\%) \\
\cline { 2 - 3 } & Healthy DC motor & 100 \\
\hline \multirow{2}{*}{$K=3$} & Shorted DC motor & 100 \\
\cline { 2 - 3 } & Healthy DC motor & 100 \\
\hline \multirow{2}{*}{$K=5$} & Shorted DC motor & 100 \\
\cline { 2 - 3 } & Healthy DC motor & 100 \\
\cline { 2 - 3 } & Shorted DC motor & 90 \\
\hline
\end{tabular}

\section{Conclusions}

In this paper, the authors presented diagnostic system. The authors conducted analysis of thermographic images of commutator of DC motor. A new method of feature extraction of thermographic images was proposed. This method was based on sum of vertical pixels and sum of all pixels. Next feature vectors were classified by K-NN classifier. Obtained results of analysis were very good for two states of DC motor.

Detecting differences of temperature is the main advantage of thermography. Moreover it is also noninvasive method of fault diagnostics. Unfortunately thermographic camera is very expensive. It costs about $1000 \div 5000$ \$. The second disadvantage of the method based on thermography is that DC motor takes time to warm up. However thermographic images can be used for monitoring of DC motors with the same type, size, operation parameters. Thermography can be also used together with other signals such as: electric and acoustic. Future researches may lead to developing a reliable diagnostic method of rotating electrical motors.

\section{Acknowledgements}

This work has been financed under AGH University of Science and Technology, AGH researcher grant in 2017 (Adam Glowacz).

\section{References}

[1] Allianz Global Corporate \& Specialty. Infrared Thermography: Determining failure or problems in electrical systems. // Risk Bulletin. No. 38 (2011).

[2] Singh, G.; Kumar, T. C. A.; Naikan, V. N. A. Induction motor inter turn fault detection using infrared thermographic analysis. // Infrared Physics \& Technology. 77, (2016), pp. 277-282. https://doi.org/10.1016/j.infrared.2016.06.010

[3] Liu, T.; Zhang, W.; Yan, S. Z. A novel image enhancement algorithm based on stationary wavelet transform for infrared thermography to the de-bonding defect in solid rocket motors. // Mechanical Systems and Signal Processing. 62-63, (2015), pp. 366-380. https://doi.org/10.1016/j.ymssp.2015.03.010

[4] Glowacz, A.; Glowacz, A.; Glowacz, Z. Diagnostics of Direct Current generator based on analysis of monochrome infrared images with the application of cross-sectional image and nearest neighbor classifier with Euclidean distance. // Przeglad Elektrotechniczny. 88, 6(2012), pp. 154-157.

[5] Koprowski, R. Some selected quantitative methods of thermal image analysis in Matlab. // Journal of Biophotonics. 9, 5(2016), pp. 510-520. https://doi.org/10.1002/jbio.201500224

[6] Jaffery, Z. A.; Dubey, A. K.; Irshad; Haque, A. Scheme for predictive fault diagnosis in photo-voltaic modules using thermal imaging. // Infrared Physics \& Technology. 83, (2017), pp. 182-187. https://doi.org/10.1016/j.infrared.2017.04.015

[7] Sebok, M.; Gutten, M.; Kucera, M. Diagnostics of electric equipments by means of thermovision. // Przeglad Elektrotechniczny. 87, 10(2011), pp. 313-317.

[8] Hreha, P.; Radvanska, A.; Knapcikova, L.; Krolczyk, G. M.; Legutko, S.; Krolczyk, J. B.; Hloch, S.; Monka, P. Roughness Parameters Calculation By Means Of On-Line Vibration Monitoring Emerging From AWJ Interaction 
With Material. // Metrology and Measurement Systems. 22, 2(2015), pp. 315-326. https://doi.org/10.1515/mms-2015-0024

[9] Li, Z. X.; Sheng, C. X.; Li, Y. J.; Xing, J. T.; Su, B. Y. Efficient Fault Feature Extraction and Fault Isolation for High Voltage DC Transmissions. // Elektronika Ir Elektrotechnika. 21, 5(2015), pp. 7-12. https://doi.org/10.5755/j01.eee.21.5.13317

[10] Li, Z. X.; Yan, X. P.; Wang, X. P.; Peng, Z. X. Detection of gear cracks in a complex gearbox of wind turbines using supervised bounded component analysis of vibration signals collected from multi-channel sensors. // Journal of Sound and Vibration. 371, (2016), pp. 406-433. https://doi.org/10.1016/j.jsv.2016.02.021

[11] Sun, Y.; Zhang, Y. G.; Wang, Y. D. Research on the Fault Coefficient in Complex Electrical Engineering. // Applied Sciences-Basel. 5, 3(2015), pp. 307-319. https://doi.org/10.3390/app5030307

[12] Sawczuk, W.; Szymanski, G. M. Diagnostics of the railway friction disc brake based on the analysis of the vibration signals in terms of resonant frequency. // Archive of Applied Mechanics. 87, 5(2017), pp. 801-815. https://doi.org/10.1007/s00419-016-1202-0

[13] Sawczuk, W. The Application of Vibration Accelerations in the Assessment of Average Friction Coefficient of a Railway Brake Disc. // Measurement Science Review. 17, 3(2017), pp. 125-134. https://doi.org/10.1515/msr-2017-0016

[14] Michalak, M.; Sikora, M.; Sobczyk, J. Analysis of the longwall conveyor chain based on a harmonic analysis. // Eksploatacja i Niezawodnosc - Maintenance and Reliability. 15, 4(2013), pp. 332-336.

[15] Li, Z. X.; Jiang, Y.; Hu, C.; Peng, Z. Recent progress on decoupling diagnosis of hybrid failures in gear transmission systems using vibration sensor signal: A review. // Measurement. 90, (2016), pp. 4-19. https://doi.org/10.1016/j.measurement.2016.04.036

[16] Deptula, A.; Kunderman, D.; Osinski, P.; Radziwanowska, U.; Wlostowski, R. Acoustic Diagnostics Applications in the Study of Technical Condition of Combustion Engine. // Archives of Acoustics. 41, 2(2016), pp. 345-350. https://doi.org/10.1515/aoa-2016-0036

[17] Deptula, A.; Osinski, P.; Radziwanowska, U. Decision Support System for Identifying Technical Condition of Combustion Engine. // Archives of Acoustics. 41, 3(2016), pp. 449-460.

[18] Jedlinski, L.; Caban, J.; Krzywonos, L.; Wierzbicki, S.; Brumercik, F. Application of vibration signal in the diagnosis of IC engine valve clearance. // Journal of Vibroengineering. 17, 1(2015), pp. 175-187.

[19] Gutten, M.; Korenciak, D.; Kucera, M.; Sebok, M.; Opielak, M.; Zukowski, P.; Koltunowicz, T. N. Maintenance diagnostics of transformers considering the influence of short-circuit currents during operation. // Eksploatacja i Niezawodnosc - Maintenance and Reliability. 19, 3(2017), pp. 459-466. https://doi.org/10.17531/ein.2017.3.17

[20] Jozwik, J. Identification and monitoring of noise sources of CNC machine tools by acoustic holography methods. // Advances in Science and Technology-Research Journal. 10, 30(2016), pp. 127-137. https://doi.org/10.12913/22998624/63386

[21] Lopez-Perez, D.; Antonino-Daviu, J. Application of Infrared Thermography to Failure Detection in Industrial Induction Motors: Case Stories. // IEEE Transactions on Industry Applications. 53, 3(2017), pp. 1901-1908. https://doi.org/10.1109/TIA.2017.2655008

[22] Garcia-Ramirez, A. G.; Morales-Hernandez, L. A.; OsornioRios, R. A.; Benitez-Rangel, J. P.; Garcia-Perez, A.; Romero-Troncoso, R. D. Fault detection in induction motors and the impact on the kinematic chain through thermographic analysis. // Electric Power Systems Research. 114, (2014), pp. 1-9. https://doi.org/10.1016/j.epsr.2014.03.031

[23] Glowacz, A. Diagnostics of Rotor Damages of Three-Phase Induction Motors Using Acoustic Signals and SMOFS-20EXPANDED. // Archives of Acoustics. 41, 3(2016), pp. 507-515.

[24] Glowacz, Z.; Glowacz, A., Simulation language for analysis of discrete-continuous electrical systems (SESL2). // Proceedings of the 26th IASTED International Conference on Modelling, Identification, and Control. Innsbruck, Austria, (2007), pp. 94-99.

[25] Duan, L. X.; Yao, M. C.; Wang, J. J.; Bai, T. B.; Zhang, L. B. Segmented infrared image analysis for rotating machinery fault diagnosis. // Infrared Physics \& Technology. 77, (2016), pp. 267-276. https://doi.org/10.1016/j.infrared.2016.06.011

[26] Sulowicz, M.; Weinreb, K.; Mielnik, R.; Zywczak, T.; Jaraczewski, M. The method of current measurement in the rotor cage bars of prototype induction motor with the use of Rogowski coils. // 2015 International Conference on Information and Digital Technologies (IDT). (2015), pp. 357-365.

[27] Glowacz, A.; Glowacz, W.; Glowacz, Z. Recognition of armature current of DC generator depending on rotor speed using FFT, MSAF-1 and LDA. // Eksploatacja i Niezawodnosc - Maintenance and Reliability. 17, 1(2015), pp. 64-69. https://doi.org/10.17531/ein.2015.1.9

[28] Glowacz, A.; Glowacz, A.; Glowacz, Z. Recognition of Monochrome Thermal Images of Synchronous Motor with the Application of Skeletonization and Classifier Based on Words. // Archives of Metallurgy and Materials. 60, 1(2015), pp. 27-32. https://doi.org/10.1515/amm-2015-0004

[29] Lim, G. M.; Bae, D. M.; Kim, J. H. Fault diagnosis of rotating machine by thermography method on support vector machine. // Journal of Mechanical Science and Technology. 28, 8(2014), pp. 2947-2952. https://doi.org/10.1007/s12206-014-0701-6

[30] Glowacz, Z. Automatic Recognition of Armature Current of Dc Motor with Application of FFT and GSDM. // Archives of Metallurgy and Materials. 56, 1(2011), pp. 25-30. https://doi.org/10.2478/v10172-011-0003-2

[31] Van Hecke, B.; Yoon, J. Low speed bearing fault diagnosis using acoustic emission sensors. // Applied Acoustics. 105, (2016), pp. 35-44. https://doi.org/10.1016/j.apacoust.2015.10.028

[32] Hemmati, F.; Orfali, W.; Gadala, M. S. Roller bearing acoustic signature extraction by wavelet packet transform, applications in fault detection and size estimation. // Applied Acoustics. 104, (2016), pp. 101-118. https://doi.org/10.1016/j.apacoust.2015.11.003

[33] Jaworek-Korjakowska, J.; Kleczek, P. Automatic Classification of Specific Melanocytic Lesions Using Artificial Intelligence. // BioMed Research International. (2016), Article Number: 8934242. https://doi.org/10.1155/2016/8934242

[34] Stepien, K.; Makiela, W.; Stoic, A.; Samardzic, I. Defining the criteria to select the wavelet type for the assessment of surface quality. // Tehnicki Vjesnik-Technical Gazette. 22, 3(2015), pp. 781-784. https://doi.org/10.17559/TV-20140124110406

[35] Hachaj, T.; Ogiela, M. R. Rule-based approach to recognizing human body poses and gestures in real time. // Multimedia Systems. 20, 1(2014), pp. 81-99. https://doi.org/10.1007/s00530-013-0332-2

[36] Koprowski, R. Automatic analysis of the trunk thermal images from healthy subjects and patients with faulty posture. // Computers in Biology and Medicine. 62, (2015), pp. 110-118. https://doi.org/10.1016/j.compbiomed.2015.04.017 
[37] Jablonski, M.; Tylek, P.; Walczyk, J.; Tadeusiewicz, R.; Pilat, A. Colour-Based Binary Discrimination of Scarified Quercus robur Acorns under Varying Illumination. // Sensors. 16, 8(2016), Article Number: 1319. https://doi.org/10.3390/s16081319

[38] Glowacz, A. Diagnostics of Direct Current machine based on analysis of acoustic signals with the use of symlet wavelet transform and modified classifier based on words. // Eksploatacja i Niezawodnosc - Maintenance and Reliability. 16, 4(2014), pp. 554-558

[39] Glowacz, A.; Glowacz Z. Recognition of rotor damages in a DC motor using acoustic signals. // Bulletin of the Polish Academy of Sciences-Technical Sciences. 65, 2(2017), pp. 187-194. https://doi.org/10.1515/bpasts-2017-0023

[40] Dudek-Dyduch, E.; Tadeusiewicz, R.; Horzyk, A. Neural network adaptation process effectiveness dependent of constant training data availability. // Neurocomputing. 72, 13-15(2009), pp. 3138-3149. https://doi.org/10.1016/..neucom.2009.03.017

[41] Jun, S.; Kochan, O. Investigations of Thermocouple Drift Irregularity Impact on Error of their Inhomogeneity Correction. // Measurement Science Review. 14, 1(2014), pp. 29-34.

[42] Roj, J.; Cichy, A. Method of Measurement of Capacitance and Dielectric Loss Factor Using Artificial Neural Networks. // Measurement Science Review. 15, 3(2015), pp. 127-131. https://doi.org/10.1515/msr-2015-0019

[43] Simunovic G.; Simunovic K.; Saric T. Modelling and Simulation of Surface Roughness in Face Milling. // International Journal of Simulation Modelling. 12, 3(2013), pp. 141-153. https://doi.org/10.2507/IJSIMM12(3)1.219

[44] Valis, D.; Zak, L.; Pokora, O. Contribution to system failure occurrence prediction and to system remaining useful life estimation based on oil field data. // Proceedings of the Institution of Mechanical Engineers Part O-Journal of Risk and Reliability. 229, 1(2015), pp. 36-45. https://doi.org/10.1177/1748006X14547789

[45] Hachaj, T. Key Frames Detection in Motion Capture Recordings Using Machine Learning Approaches. // Image Processing and Communications Challenges 8. Book Series: Advances in Intelligent Systems and Computing. 525, (2017), pp. 79-86. https://doi.org/10.1007/978-3-319-47274-4_9

[46] Chandrasekaran, M.; Devarasiddappa, D. Artificial neural network modeling for surface roughness prediction in cylindrical grinding of $\mathrm{Al}-\mathrm{SiCp}$ metal matrix composites and ANOVA analysis. // Advances in Production Engineering \& Management. 9, 2(2014), pp. 59-70. https://doi.org/10.14743/apem2014.2.176

[47] Valis, D.; Zak, L.; Pokora, O.; Lansky, P. Perspective analysis outcomes of selected tribodiagnostic data used as input for condition based maintenance. // Reliability Engineering \& System Safety. 145, (2016), pp. 231-242. https://doi.org/10.1016/j.ress.2015.07.026

[48] Klancnik, S.; Ficko, M.; Balic, J.; Pahole, I. Computer Vision-Based Approach to End Mill Tool Monitoring. // International Journal of Simulation Modelling. 14, 4(2015), pp. 571-583, https://doi.org/10.2507//JSIMM14(4)1.301

[49] Ganovska, B.; Molitoris, M., Hosovsky, A.; Pitel, J.; Krolczyk, J.B.; Ruggierio, A.; Krolczyk, G. M.; Hloch, S. Design of the model for the on-line control of the AWJ technology based on neural networks. // Indian Journal of Engineering and Materials Sciences. 23, 4(2016), pp. 279287.

[50] Hu, Z. B.; Su, J.; Jotsov, V.; Kochan, O.; Mykyichuk, M.; Kochan, R.; Sasiuk, T. Data Science Applications to Improve Accuracy of Thermocouples. // 2016 IEEE 8th International Conference on Intelligent Systems (IS). (2016), pp. 180-188.
[51] Jamroz, D; Niedoba, T. Application of Multidimensional Data Visualization by Means of Self-Organizing Kohonen Maps to Evaluate Classification Possibilities of Various Coal Types. // Archives of Mining Sciences. 60, 1(2015), pp. 39-50. https://doi.org/10.1515/amsc-2015-0003

[52] Gorny, Z.; Kluska-Nawarecka, S.; Wilk-Kolodziejczyk, D.; Regulski K. Methodology for the construction of a rulebased knowledge base enabling the selection of appropriate bronze heat treatment parameters using rough sets. // Archives of Metallurgy and Materials. 60, 1(2015), pp. 309312. https://doi.org/10.1515/amm-2015-0050

[53] Frigieri, E. P.; Campos, P. H. S.; Paiva, A. P.; Balestrassi, P. P.; Ferreira, J. R.; Ynoguti, C. A. A mel-frequency cepstral coefficient-based approach for surface roughness diagnosis in hard turning using acoustic signals and gaussian mixture models. // Applied Acoustics. 113, (2016), pp. 230-237. https://doi.org/10.1016/j.apacoust.2016.06.027

[54] Koprowski, R.; Lanza, M.; Irregolare, C. Corneal power evaluation after myopic corneal refractive surgery using artificial neural networks. // BioMedical Engineering OnLine. 15, (2016), Article Number: 121. https://doi.org/10.1186/s12938-016-0243-5

[55] Valis, D.; Zak, L.; Pokora, O. System Condition Estimation Based on Selected Tribodiagnostic Data. // Quality and Reliability Engineering International. 32, 2(2016), pp. 635645. https://doi.org/10.1002/qre.1778

[56] Regulski, K.; Jakubski, J.; Opalinski, A.; Brzezinski, M.; Glowacki, M.; The Prediction of Moulding Sand Moisture Content Based on the Knowledge Acquired by Data Mining Techniques. // Archives of Metallurgy and Materials. 61, 3(2016), pp. 1363-1368.

https://doi.org/10.1515/amm-2016-0277

\section{Authors' addresses}

Adam Glowacz, Assistant Prof. Dr.

AGH University of Science and Technology,

Faculty of Electrical Engineering, Automatics, Computer Science and Biomedical Engineering,

Department of Automatics and Biomedical Engineering

al. A. Mickiewicza 30, 30-059 Krakow, Poland

E-mail: adglow@agh.edu.pl

\section{Andrzej Glowacz, Assistant Prof. Dr.}

AGH University of Science and Technology,

Faculty of Computer Science, Electronics and Telecommunications Department of Telecommunications

al. A. Mickiewicza 30, 30-059 Krakow, Poland

e-mail: aglowacz@agh.edu.pl

Zygfryd Glowacz, Associate Prof. Dr.

AGH University of Science and Technology,

Faculty of Electrical Engineering, Automatics, Computer Science and Biomedical Engineering,

Department of Power Electronics and Energy Control Systems al. A. Mickiewicza 30, 30-059 Krakow, Poland

E-mail: glowacz@agh.edu.pl 